Article

\title{
Farms in Progress-Providing Childcare Services as a Means of Empowering Women Farmers in South Tyrol, Italy
}

\author{
Verena Gramm ${ }^{1, *(\mathcal{D}}$, Cristina Dalla Torre ${ }^{1}$ and Andrea Membretti ${ }^{1,2}$ \\ 1 Institute for Regional Development, Eurac Research, 39100 Bolzano, Italy; cristina.dallatorre@eurac.edu (C.D.T.); \\ andrea.membretti@eurac.edu (A.M.) \\ 2 GLOMOS-Center for Global Mountain Safeguard Research, 39100 Bolzano, Italy \\ * Correspondence: verena.gramm@eurac.edu
}

Received: 13 November 2019; Accepted: 1 January 2020; Published: 8 January 2020

check for updates

\begin{abstract}
In recent years, social farming has developed into an opportunity for income diversification in the South Tyrolean agricultural sector. In the northern Italian province, predominantly women farmers implement the provision of social services on farms. Starting from rural gender studies and women empowerment-literature, we hypothesize that social farming promotes the empowerment of the involved women. Accordingly, our study investigates the recognized impacts of offering farm-based childcare services on three types of power: power to, power with, and power within. In order to test our hypothesis, we conducted semi-structured interviews with seven women farmers that provide childcare services and with four experts. The results show that the provision of childcare services has enhanced the autonomy of women farmers and has had positive impacts on their skills and competences. This activity has changed their social role in the community by revalorizing rural lifestyles and by enabling the reconciliation of work and personal life for working mothers. Nevertheless, women farmers have recognized some negative effects on their workload, and on their interfamilial as well as other social relations. Finally, the study discusses the relationship between the specific ethno-linguistic context in South Tyrol and the effects of the activity of childcare provision on women farmers' empowerment.
\end{abstract}

Keywords: social farming; South Tyrol; women in agriculture; social entrepreneurship; empowerment

\section{Introduction}

Women worldwide play an important role in agriculture and in food security. Nevertheless, they still have limited access to resources, such as soil, production means, and money [1-3]. As key actors in family farms in Europe, women contribute in several ways to the farming income, although their work is often characterized by invisibility and low recognition [4-6], and is undervalued when compared with male farmers' work [7-10].

Lately, owing to the emerging relevance of farm-diversification strategies in European family farms, new opportunities for women to obtain their own space of action have opened up [11]. Thanks to their innovative entrepreneurial engagement in the frame of a multifunctional agriculture, women make use of and demonstrate their manifold skills and competences [12] and increase the visibility of their important work in society [5,13]. Additionally, they break out of the dependency trap by gaining a personal income [11]. Social farming can be considered an example of arrangement in the frame of multifunctional agriculture [14,15]. It is an activity designed to make use of agricultural resources-plants, animals, and abiotic assets-for educational, care giving, health promotion, or socially inclusive services [16]. Social farming can, therefore, be a diversification activity 
for farmers to increase their income and to secure their subsistence [17], but also a form of social entrepreneurship. According to this approach to entrepreneurship, social change towards inclusion is counted as part of the output together with economic revenues [18].

A number of scholars have dealt with the role of women farmers in the development of diversification activities [11,19] and their contribution to women's empowerment $[6,13,20]$. Others have investigated the linkage between women's engagement in social entrepreneurship and empowerment [21-23]. To date, however, little attention has been paid to the empowerment potential of women's participation in social farming.

In the north Italian province South Tyrol, mainly private family farms have integrated social farming in their agricultural activities. Approximately 50 out of the 130 farms engaged in social farming in 2017 offer childcare services for children aged 0-4. The key providers of this service are women farmers; they are organized in the social cooperative Learning-Growing-Living with women farmers [24], which was founded in 2006. Owing to its relevance for the rural province of South Tyrol, this initiative was taken as a case study in the European Union (EU) project SIMRA. Social Innovation in Marginalised Rural Areas (SIMRA) is a project funded by the European Union's Horizon 2020 research and innovation programme. SIMRA seeks to advance understanding of social innovation and innovative governance in agriculture, forestry and rural development, and how to boost them, particularly in marginalized rural areas across Europe, with a focus on the Mediterranean region (including non-EU), where there is limited evidence of outcomes and supporting conditions (www.simra-h2020.eu).

With this study, we aim to explore the empowerment of women farmers thanks to social farming as a form of social entrepreneurship. The following research question guides our study: what impacts does the activity of farm-based childcare provision have on the empowerment of women farmers in South Tyrol? As a base for the investigation, we applied the empowerment concept provided by Rowlands [25] and Kabeer [26], applied in the study of Annes \& Wright [6]. Through a qualitative approach and based on the perspectives of women farmers offering childcare, the study shows which effects the activity as childminder has on women farmers' empowerment.

This work contributes to the literature on gender and farm diversification in general and in particular on the potential of social farming to empower women. Moreover, the concept of women's empowerment has mainly been applied in the context of developing countries $[6,13]$. With this paper, we contribute to the understanding of this process in other settings. Finally, this paper aims at enlarging the knowledge on social farming in South Tyrol by investigating the phenomenon from a sociological point of view.

\section{State of the Art}

\subsection{Gender Roles on European Family Farms}

Even if there is agreement on the importance of family-conducted farms in food production, this dominant farming system in Europe can be seen as an upholder of traditional patriarchal values [13]. In patriarchal organized family farms, the male farmer is mainly responsible for agricultural production, while the duties of women farmers cover many diverse fields; they are responsible for housekeeping, for the care of family members, for gardening, and for ad-hoc farming support [27].

Women farmers' tasks on the farm are not formally recognized, nor economically compensated (i.e., not paid). As a consequence, they are frequently economically dependent on the male farmer and their work remains invisible $[5,6,28]$, even though it is essential for the survival of family farms. Evidence for the invisibility of women in agriculture in the past is also shown by the absence of their inclusion as 'workforce' in agricultural statistics [29,30], as well as in their underrepresentation in the agricultural lobby and in farmers' associations [31]. Moreover, in European countries, patrilineal farm-succession is still the tradition [32]. Therefore, women in farmers' families are disadvantaged 
regarding access to agricultural resources and decision-making. Male farmers are still the formal decision makers and the representative of the farm to the world outside [31].

A review of migration analysis has revealed that mobility patterns in rural Europe are gendered with young women leaving rural areas at higher rates than young men [33]. The emigration of young rural women is perceived as a major threat to local development in terms of declining birth rates and motivation for young rural men to follow [34]. Traditional gender roles can be one reason for female out-migration from rural areas $[35,36]$. Obviously, hard factors like employment opportunities, salary, education possibilities, infrastructural endowment, or the housing situation are also relevant in deciding the place of residence. Specifically related to agriculture, aspects such as the cultural climate, the prospects of hard work and little free time, the political framework, the quality of life, social relations, and networks determine whether women are attracted to this environment [12]. This also explains the low share of young women in the family farm labor force in the EU [4]. Current social and economic transformation processes help women farmers to break out from traditional gender roles and old patterns. The trends towards individualization and pluralization of society also influence the attitudes and the behavior of peasants. The manifold possibilities for education and self-realization today are available for farmers and their families $[37,38]$. They are in contact with different lifestyles outside the agricultural milieu, which is likely to change their own ways of living. Owing to out-migration from rural areas, the number of people engaged in agriculture is decreasing. Many women who marry a male farmer come from a non-agricultural environment [39]. Thanks to their different backgrounds, they bring new insights and competencies to the farm. Their cultural identity is based on values that frequently do not coincide with the traditional moral concepts in agriculture. Consequently, traditional gender roles in European family farms have begun to dissolve [28].

In addition to these societal trends, economic changes trigger the breakout from the patriarchal division of roles in agriculture. The high economic pressure on small-scale family farms forces farmers to generate additional income for the household. Therefore, different developments can be observed in Europe. On the one hand, off-farm employment of one spouse causes the transition either to a "feminized" or to a "masculinized" agriculture [10-12]. On the other hand, family farms introduce new business ventures to diversify their income sources. The combination of farm-based activities in the context of diversification [17] and of multifunctional agriculture [40] call women to bring their competencies into the farm businesses; their role changes thanks to the opportunity to integrate economic activities and to develop a professional identity as "new rural entrepreneurs" [19]. This development might change gender relations through the creation of new areas of responsibility for women farmers. They allow the creation of "a room of one's own" cit. in the works of $[6,41]$, that is, to become empowered by building women's own labor domains [19].

\subsection{The Role of Women Farmers in Social Farming and the Empowerment Potential of Social Entrepreneurship}

Employment outside agriculture and farm-based entrepreneurship open new possibilities for women farmers to gain a personal income and become economically independent. Conversely, these additional activities can result in overwhelming hours of female work, because the paid job is added to the work in the household and in child rearing, which becomes "the second shift" in Hochschild's words [42]. This may increasingly lead women farmers to face the question of whether sacrificing their free time is worth gaining a personal income [28].

Next to processing and marketing of agricultural products and to agritouristic and gastronomic offers, women farmers increasingly engage in offering farm-based social services. According to Di Iacovo \& O'Connor [16], social farming in Europe is often a women-related duty. In Italy, for example, the typical worker in agricultural social cooperatives is "young, female, and qualified"; in $2009,70 \%$ of the workforce in this sector were women (ibid.). Heggem [12] claims that social farming and agritourism demand new skills and competencies from farmers, often related to a higher level of education/training. Although the educational attainment of female farm managers in the EU is lower than that of males, the general educational level of women in the EU is higher. One out of three women 
aged 15 to 64 years in 2010 held a degree of tertiary education, whereas only $27 \%$ of men in the EU had this educational level [43]. Therefore, rather women than men could be attracted by the agricultural side-activities that require professional skills and competences, which in consequence could retain them in rural areas.

Although there is little literature about the role of women farmers in social farming activities, some researchers deal with women's empowerment potential of social entrepreneurship in agriculture. Kimbu \& Ngoasong [44] looked at the social transformation of the "self" of women engaging in social entrepreneurship in Cameroon. Their status transformed from the traditional role of being a housewife to the role of owner-managers of social enterprises in a male-dominated setting. According to Sidhu \& Kaur [45], benefits of entrepreneurship to rural women include employment generation; economic independence; and personal and social capabilities like self-confidence, leadership, and social interaction. Datta \& Gailey [22] categorize such effects under the frame of empowerment, which is embedded in the business model of female social entrepreneurship.

Much of the reviewed literature refers to non-European countries. Women's empowerment as a concept to assess gendered power relations in agriculture was usually applied in developing countries $[2,3,21,22,46]$. Despite the different socio-economic situations of women in these countries as starting point for the development of empowerment, the cited literature provides interesting insights into the effects entrepreneurship had on gendered power relations. Recently, some studies also adapted the concept to investigate the empowerment potential of diversification activities in agriculture in Western countries [6,13]. Moreover, Alkhaled \& Berglund [47] analyze women's empowerment through social entrepreneurship in Sweden and Saudi Arabia. They argue that social entrepreneurship allows women to shift from a status of subordination to act collectively for empowerment, challenging existing oppressive structures. Simultaneously, they stress the necessity to differentiate between empowerment and emancipation in the debate of female entrepreneurship They apply the definition of Inglis [48] of empowerment and emancipation. Accordingly, empowerment is defined as "a means for people to develop capacities through which they can act successfully within the existing system and structures of power". Emancipation, on the other hand, "concerns a critical analysis of power that might bring about resistance, through which existing systems of power can be subverted". These studies represent the frame of our investigation and supported us in designing a suitable research concept.

\section{Theoretical Framework}

\subsection{Empowerment}

To analyze the effects of providing childcare services on women farmers' working and living conditions in South Tyrol, we make use of the concept of empowerment. It is frequently applied by feminist scholars to describe women's capacity for challenging patriarchal structures. Kabeer [26] defines women's empowerment as the "process by which those who have been denied the ability to make strategic life choices acquire such an ability". Next to the access of women to material, human, and social resources, Kabeer [26] and other authors [49] value agency as a crucial element of women's empowerment. Agency is understood as the ability to define one's goals and to act upon them. It can take the form of decision-making, bargaining and negotiation, deception and manipulation, subversion and resistance, as well as reflection and analysis [26]. The presence of agency is determined most frequently by the concept of control, in terms of having a say in the usage of resources [21]. By bringing together the access to resources with the agency, women have the potential to achieve valuable ways of being and doing. The achievement of personal well-being represents the outcome dimension of empowerment [26].

Empowerment is inescapably intertwined with disempowerment: a person who becomes empowered, once must have been constrained by a lack of power in making her or his own life choices. Thus, empowerment describes the process of change [26], in our case, the shift of power to women farmers of shaping their lives in the direction they want to. Empowerment is perceived 
personally, and thus defined by the person referring to her or his personal life experiences, personality, and aspirations, but is also dependent on context and culture [2].

Some scholars suggest a multidimensional concept of power to make women's empowerment tangible [6,25]: "power to" includes agency [26] as well as its basic requirement; that is, access to tangible (financial) and intangible (human and social) resources. The capacity to collectively organize things within a network with the purpose to pursue common goals and to gain new resources and skills is defined as "power with". "Power within" is the personal self-esteem including the ability to see oneself as an agent of change. This type of power is strongly interlinked with challenging dominant cultural representations and making abilities and skills performed covertly visible in the public sphere [6].

\subsection{Social Entrepreneurship in Agriculture for Women Empowerment}

Social entrepreneurship aims at the "innovative use of resources to explore and exploit opportunities that meet a social need in a sustainable manner" [50] (p. 203) and combines economic production and commercial objectives with the delivery of beneficial societal outcomes [18,51]. Social farming transforms agriculture from a mere primary production sector into a multifunctional one, where social services are delivered making use of rural resources [14,15]. Social farming can thus be framed as a form of social entrepreneurship. Within this discourse, farmers provide social services under market conditions on their farm and generate additional income [17]. Social farming also provides the opportunity to redesign roles and production modes, which enable income diversification and empowerment of disadvantaged groups [52], such as women in rural areas.

In being a professional activity that requires specific knowledge on pedagogy and rural resources and the modification of work processes, social farming is an opportunity for acquiring new skills and capacities through specific training. According to Haugh \& Talwar [21], the acquisition of new knowledge and work processes are among the activities through which women determine social change and gain control over resources and processes. In their emancipatory social entrepreneurship model, membership in the business empowers women in four ways: economically, in generating their own income; personally, in increasing skills and in pursuing their own interests; socially, in gaining respect from the community and in building their own networks; and culturally, in transforming traditional gender roles and farming roles.

Women engaging in social farming are motivated by the desire to be empowered and autonomous. However, in certain contexts, the empowerment process in social entrepreneurship is limited by patriarchal structures rooted in the local cultural identity. These structures refer, for example, as mentioned in the state of the art on gender roles in agriculture, to the allocation of resources (land). According to Alkhaled \& Berglund [47], empowerment is distinguished from emancipation, because it does not challenge the pervasive patriarchal order. This means that through social farming, women acquire autonomy, professionalization, and self-realization opportunities, but in certain contexts, they still act within the patriarchal system.

\section{Methodology}

In order to explore the effects of providing farm-based childcare services on women farmers' empowerment, we chose a qualitative approach. This approach helps to formulate new insights from the point of view of those directly affected: women farmers providing childcare services on their farm. We selected the seven interviewees with the support of the social cooperative Learning-Growing-Living with women farmers and according to a set of predefined criteria. These criteria should reflect the diversity of the 50 existing farm-based childminders in South Tyrol in order to have a heterogeneous sample and to gather as varied results as possible. The criteria were the following: age, previous activity (off-/on-farm), relationship status, parenthood, distance from larger towns, and partner working off-/on farm. Additionally, we decided to interview four experts to complement the opinions of the individuals involved. We spoke with the president and the director of the social cooperative, with the provincial 
secretary of the women farmers' association, and with a social scientist at the Free University of Bolzano who has been studying social farming in South Tyrol for some years.

For collecting the data, we chose the qualitative semi-structured interview. The content of the interview guidelines addressed to women farmers focused, on the one hand, on the motivations and the decision-making process of women farmers to provide childcare services, and on the other hand, on changes in their working and living conditions determined by the activity as childminder. The expert-interviews referred to the framework conditions-that is, the enabling and hindering factors - of the activity as farm-based childminder. Additionally, we spoke about the changes the experts have observed on women farmers' work and life thanks to their new job as farm-based childminders.

Being the study conducted in the frame of Horizon 2020 project SIMRA, the research design complies with the legal guidelines on research ethics. The ethical clearance procedure is described in the Chapter 3.2.2. Ethics, safety, and regulatory risks of the SIMRA Deliverable 5.1 (http://www.simra-h2020.eu/wp-content/uploads/2018/06/SIMRA-D5.1_Case-Study-Protocols-andFinal-Synthetic-Description-for-Each-Case-Study-1-1.pdf). We carried out all interviews between May and September 2018. The interviews lasted $50 \mathrm{~min}$ on average. We recorded and transcribed them literally. The interview transcripts were subjected to a structuring content analysis according to Mayring [53], which has the aim to extract and summarize qualitative data material according to previously defined topics, contents, and aspects. This type of analysis starts with a theory-driven definition of categories and the explicit description of which text components fall under each category. The next step is to identify anchor examples for the categories. Finally, coding rules are established to allow clear attributions in the event of problems of demarcation between categories. These rules are summarized in a coding guideline that supports the further coding process.

For the definition of the analysis categories in this study, we considered the multiple dimensions of power mentioned in Section 3.1. Specifically, we applied some categories suggested by the literature to investigate the empowerment potential of women farmers' job as childminder. After an initial coding process, additional inductively derived analysis categories were incorporated into a final coding guideline together with the deductively defined categories. It included the following ten categories divided in the three types of powers. To explore "power to", the process of decision making of South Tyrolean women farmers to start the activity of providing childcare services has been studied. That includes (i) their motivations; (ii) their access to material, human, and social resources; and (iii) the hurdles and enabling factors in the decision-making process. For the dimension "power with", we considered the role of the network of women farmers within the social cooperative Learning-Growing-Living with women farmers. In this regard, we investigated (iv) the collectively organized measures required to achieve common goals and new skills and $\mathrm{v}$ ) the social relations within the network. To the third type, "power within", we assigned following indicators: (vi) changes in the character and wellbeing of women farmers, vii) changes in their attitudes, and viii) their future prospects concerning their activity. On the basis of this coding guideline, the work on the text material started. With the support of QCAmap, an open access web application for the systematic text analysis, we assigned matching categories to text passages related to specific topics. As output of the coding process, the application provided an Excel-table with the categories and the assigned text passages in a structured way. Subsequently, we could paraphrase, generalize, and summarize the coded text passages as suggested by Mayring [ibid]. The result of the analysis is a topic-related summary of the interviews.

\section{Context of the Study}

South Tyrol is a border region in the north of Italy, where historical occurrences condition cultural diversity, which is represented by the co-existence of different languages and cultures. In the province of Bolzano, three language groups exist: German, Italian, and Ladin. The German and Ladin groups are considered as ethnic minorities on a national level, and are thus protected in the South Tyrolean autonomy statute [54]. They represent the majority on a provincial level; that is, $62.3 \%$ and $4.1 \%$ of the 
South Tyrolean population, respectively [55]. The language groups have different cultural backgrounds with regard to the territory, to mountain farming, and to nature as a whole [56]. The German and Ladin language represent a collective identity strongly linked to peasant lifestyle [57], while the Italian speaking population is mainly the descendant of immigrant industrial workers and officers from different parts of Italy from the fascist period. The latter mainly lives in the province's larger cities, Bozen, Meran, and Brixen [58]. Forced integration of all three ethnic groups under fascist cultural homogenization policies [59] caused traumatic experiences and resistance. This has resulted in conflictual relationships among the groups [60-62].

In South Tyrol, the typical form of an agricultural enterprise is the family farm. More than half of the farms carry out agricultural activities as a source of secondary income and work outside agriculture, sometimes also to ensure the farm's survival. Nevertheless, $7.8 \%$ of overall employment in the province in 2017 was in the agricultural sector [63], whereas nationally, it was only $3.6 \%$ [64]. This figure can be explained on the one hand by the morphological conformation of South Tyrol, which is $90 \%$ composed by mountains, and thus unsuitable for the establishment of large industries [61]. On the other hand, the provincial government has autonomy in defining policies for the agriculture and spatial planning sectors [65], and it has assigned a significant role to local farmers [61]. South Tyrolean farmers have played an important role in influencing policy to try to protect their low-profit, small-scale farms. In so doing, they seek to preserve their rural lifestyles and values [66]. Furthermore, the development of tourism as one important pillar of the local economy and its strong linkage to landscape and agriculture has strengthened the support for traditional occupation in the agrarian sector [67]. In addition to the landscape preservation function that agriculture provides to the touristic sector, agricultural lifestyle is another asset of the local identity, which is presented to visitors. The high number of guests looking for authentic experiences in turn provides farmers with new diversification opportunities and enhances the economic viability of agriculture [61]. Summarizing the historical developments in the study region, it is evident that the special role and the preservation of agriculture is of particular interest for the Germanophones and Ladins and is linked to the survival of their identity. Politically supported and encouraged by a win-win relation between tourism and agriculture, but also fostered by the strong will of the farmers themselves to maintain their farm businesses, the sector is currently of great importance for the socio-economic viability of South Tyrol.

Regarding gender roles in South Tyrolean farms, these are closely linked to the fact that the identity of the Germanophone language group has developed around the principles of rurality, patriarchy, and Catholicism [68]. Statistics confirm the traditional patrilineal farm succession and the underrepresentation of women in leading positions in agriculture. Only $13.5 \%$ of the 20,247 South Tyrolean farms are managed by women. In contrast, women manage $30.7 \%$ of farms in the whole of Italy [69] and 27.9\% of European farms [70]. Another example of the underrepresentation of female farmers in decision-making and official positions in agriculture is their absence in leading positions of the main South Tyrolean farmers' association. Furthermore, the separation of gender in agriculture in South Tyrol is evident through the existence of a women farmers' association. Women farmers have created their own organization to strengthen their position in agriculture and in society and to support women in economic, cultural, and social regards. According to a study by Matscher et al. [71], fulltime South Tyrolean women farmers tend to accept the traditional gender-differentiated division of labor; they see it as their duty to do the housekeeping, to take care of their children or relatives, or to work in the garden. The male farmer in contrast is responsible for the agricultural production. Even though most of the farming couples divide the decision-making power by their area of responsibility, decisions concerning the entire farm and the farming income are rarely taken together. Therefore, it is evident that women farmers with no off-farm job or farm-based side activity are still financially dependent on their husbands [72].

In South Tyrol, mainly women farmers work in social farming, offering educational and care giving services, work integration, and animal-assisted therapy. In 2006, a network of the South Tyrolean women farmers founded the social cooperative Learning-Growing-Living with women farmers. It was 
the first organization dealing with social farming in South Tyrol and, in particular, to provide childcare services on farms [73]. The aim of the cooperative was to give women farmers an opportunity to earn their own money, as at that time, many of them were economically dependent on their husband. In 2017, nearly 50 women farmers were employed as childminders [74]. The families benefitting of the childcare service are in general working parents of 0-4-year-old children, not only living in rural areas and looking for a decentralized provision of the service, but also living in small towns and appreciating a different form of childcare on offer, closer to nature and to rural lifestyles. The social cooperative as organizational framework of the childcare services coordinates demand and supply, supports the childminders in bureaucratic issues, organizes training programs, represents their interests in the political sphere, and manages marketing.

\section{Results}

The seven interviewed women farmers have different backgrounds regarding their involvement in farm work. We identified one main difference among the interviewed women relating to their level of involvement in the farm work before starting the activity of farm-based childcare. Four women farmers were employed off-farm before they started the activity as a childminder, and the other three worked full-time at the farm. For the first group, the decision to provide childcare services was linked to the fundamental decision of whether to work outside or inside the farm environment. Additionally, their age and family situation influenced the empowerment process. The three full-time women farmers were already somewhat older than the ones with off-farm employment and their children had already grown up. It was their wish to get a second chance for education and to start a new project. During the period of decision-making, three of the four younger women were either raising their young children or planning to have children soon. One women farmer had to stay at the farm, because her mother died. Because of various backgrounds, the interviewees experienced different impacts of the activity on their empowerment. In the following sections, results of the analysis have been organized according to the three dimensions of empowerment, as explained in the theoretical framework (Section 3.1.). They are: "power to", "power with" and "power within". All the statements of the interviewed women farmers reported in the following sections have been cited with the abbreviation WOMXXX; and experts' opinions that complement the results with EXPXXX.

\section{1. "Power To"}

In this section, we summarize statements of the interviewees on their ability to take life decisions, as well as reflections on their motivations to act upon these decisions. Access to resources plays an important role in their ability to make life decisions.

\subsubsection{Motivations to Start the Activity as Childminder}

Some of the interviewed women started the activity because they wanted to generate an additional income for themselves and to contribute to the family household. Income generation for women farmers was also the basic motivation for expert EXP001 to create the social cooperative more than ten years ago. For some, however, starting to provide farm-based childcare was necessary to help the family business survive. The interviewees also see the profession as childminder as an opportunity to combine work and care for their own children: "Then I got pregnant $[\ldots]$. And then I had to do $35 \mathrm{~h}$ again after motherhood and that was effectively too much for me. [ ... ] now I'm just at home with [my son], I can manage a lot myself. And I can connect everything better" (WOM008). Strongly interlinked with the desire to gain a personal income was the desire for self-reliance: "so you have a certain amount of independence, of autonomy" (WOM010). Some women expressed future-oriented motivations: " ... I wanted my pension; it was just a thought for the future [ ... ] especially the pension and then the social insurance [ ... ]. It's worth a lot." (WOM010). Furthermore, the wish to do something for themselves, to use training opportunities, and to have their own field of action on the farm led women farmers to become active within social farming. Two women were willing to 
revitalize the farm through childcare provision: "my children are actually all grown up and have left the house and we have a big house and with the children there is again a lot, a lot of life in the house and that is simply beautiful. Otherwise, it would be very quiet and desolate" (WOM012). In addition, practical drivers determined the decision: "because I can't go to work [off-farm] so someone is on the farm, because my husband works, too. Then someone has to be here for the animals and for someone to be in the house" (WOM012).

\subsubsection{Access to Resources}

The membership in the network of women farmers that gave birth to the social cooperative is to be considered a social resource, as it opened up the opportunity to become a childminder: "I don't think I would have joined it [the social cooperative] myself. I'm member of the women farmers' association, there they told me that [ ... ] I would have been the right one for them" (WOM013). When it was set up, the founders encouraged the members of the network to participate in the training courses and to start the activity as a childminder (EXP001, EXP014). Finally, a widespread network in the community helped the women farmers to be recognized as a childminder and to find enough demand for their service offer.

The provision of farm-based childcare services does not require major structural investments. In comparison with running an agritourism business, which requires the construction or refurbishing of accommodations, this social service can be offered in the original farm building and outside in nature. The women had to invest financial and time resources into training to become childminder according to a specific approach of pedagogics, focusing on environmental education (called "nature pedagogics"). The interviewees did not, however, perceive the investment in the training as an obstacle to overcome. To the contrary, the provision of childcare services enabled women farmers to have access to financial resources, as they gain a personal income. The opinions on the salary differ significantly. Some interviewees reported an improvement in income: "I didn't make any more money with the part-time jobs I had first. And that's nice money you get now, if you can stay at home, you don't have to go anywhere" (WOM009). Others reported being better off beforehand: "It's a bit difficult in terms of salary, because you simply earn a little bit less" (WOM002). Also, one of the interviewed experts (EXP025) claims a higher salary for women farmers. Nevertheless, the interviewees agree on the fact that the salary depends strongly on the number of children cared for and the working hours. Most of the women farmers see the salary as a personal income, but certainly, they contribute to the family household and support their children as well as the farm. Two experts confirmed the improvement of the financial situation of women farmers compared with the initial phase of the social cooperative: "You have no idea what was at the beginning. A common farm bank account. That can't be true. [ ... ] So we did a lot of sensitization work about it" (EXP001); "it was important to us that the woman farmer has her own account and that we transfer the salary to her account" (EXP014).

By access to "time resources", we mean the availability of "spare" time, which allows women farmers to insert a new activity into their daily lives. The results report that, for the group of women that previously worked full time on the farm, time resources were limited; owing to their manifold tasks in the household, on the farm, and in child-rearing, women farmers had to reorganize their farm duties in accordance with the family members and mutual support within the family. Time had to be planned more efficiently, with greater flexibility than before and accounting for the presence of the children and the needs of the children's parents. Some women farmers said that their husbands had to accept a reduction in the women's contribution to farm work (WOM009, WOM002). The family members also had to understand and accept that the woman had less time to satisfy their needs immediately. A strategy mentioned by the interviewees to overcome the lack of time was the postponement of farm and household tasks to the evening or to the weekends. Therefore, they had to renounce on their free time; that is, time for voluntary work, social relations, or excursions. "So, my household often waits for me on the weekends. I start every day at 05.00 o'clock and I work nonstop until 21.00-21.30 o'clock. As soon as the parents come to pick up their children, my work as housewife and farmer starts" (WOM012). All the experts confirm that 
the farm-based childminders have to cope with a high workload (EXP001, EXP004, EXP014, EXP025). One of the interviewed stated that women farmers can become overloaded with work and that they are "exploiting themselves" (EXP025). Conversely, women farmers that formerly worked off-farm perceived an increase in time resources for the farm work and the household: "I am more in the stable now since I look after the children. I have more time to look after the animals. [ ... ] you're just around here, you can go into the garden, you can hang laundry." (WOM009). "There's no stress driving to work anymore" (WOM011). Indeed, they recognized a decrease of workload and stress. Nevertheless, one interviewee of this group observed that she works from the early morning until the night and she has reduced the amount she sleeps (WOM010).

Some interviewees mentioned the importance of having social skills and the passion to work with children as personal preconditions that enable the activity as childminder (WOM012, WOM13). Additionally, the training courses organized by the social cooperative facilitated the access to skills: "That you think about what you want $[\ldots]$. And then to [ ... ] become clear, where are my limits, how far do I go, what is my area of acceptance" (WOM010). According to the women farmers, the training courses were very important in providing them with a new perspective on childcare according to nature pedagogic principles. The training gave them the instruments to implement the farm-based services and to cope with challenging situations during the child assistance. One of the experts affirmed that the women farmers had to learn how to cope with their multifaceted duties: " ... they need to learn how to handle the work. [ ... ] That is our task as a cooperative. We do supervision, we do personal development" (EXP001). Thanks to the supervision of the social cooperative and the training courses, women farmers are supported in this issue.

\subsubsection{Decision-Making Process}

Inserting an on-farm business such as providing childcare services affects all the farm family members and the working processes at the farm. The presence of non-family children disturbed some of the family members, as well as women's employment, reducing their availability for farm or family issues. Therefore, the decision-making to start the business did not only concern the women farmers: "[ ... ] that was already a shared decision [ ... ]. It also affects the other [own] children [...] because I often don't have as much time as they want" (WOM012). It was important to find appropriate solutions regarding work organization and division that satisfied all the concerned persons. The support of the whole family was essential for decision-making: "[ ... ] it's got to be the whole family behind it, or you can't do it. Especially on the farm, because every day there are other jobs to be done" (WOM002). Two experts (EXP001, EXP014) observed that, frequently, it was the economic benefit of the service provision for the farm that made the male farmers accept their wives' activity: "The farmer sees the value of the woman. [ ... ] also through the money" (EXP001). In the starting phase of the initiative, the lack of trust by the male farmers in the competencies of the women farmers represented an initial hurdle to start the activity (EXP001). As we only interviewed women farmers, who actively provide childcare services, we assume that, in addition to mutual support between the women and from their families, their negotiation skills enabled them to act upon their decision to become childminders. Nevertheless, the results show that the freedom of women farmers in their decision-making was limited by the needs of the family members and the traditional duties in the household and the farm.

\section{2. "Power With"}

"Power with" is the collective dimension of power and relates to the capacity to collectively organize things in the network of the social cooperative with the purpose to achieve common goals, create new resources, and develop skills. 


\subsubsection{Collectively Organized Measures to Gain Common Goals and New Skills}

One first result of the network was the organization of an accredited training course for childminders according to the principles of nature pedagogy. The course includes subjects like developmental psychology and education of children, health education, or nutrition education (EXP001, EXP004, EXP014). All the interviewees reported the important contribution of the training to their access to skills, as already mentioned above.

The social cooperative allows the women farmer to focus on her childminding work, as it takes over bureaucracy and lobby tasks (EXP001). The members of the network meet in formal meetings, organized by the social cooperative: "We have an exchange of experiences, we have courses, there is a plenary meeting where people meet, [...]" (WOM002). These exchange opportunities enlarged the women farmers' capabilities in their daily job, and created a feeling of belonging and of being supported by someone.

As a childminder, women farmers work under better pension and social insurance conditions than as the farmer's wife. Thanks to the political activity of the cooperative's president, the collective contract of childminders could even be improved: "And above all also the pension and then the social security which we have now received with the new contract last year. It is effective that you can also say that this is a profession, even in the longer term, the pension is secured and I am fine. That is worth a lot" (WOM010).

\subsubsection{Social Relations within the Network}

All the interviewees are members of the social cooperative Learning-Growing-Living with women farmers. The network consists of more than 116 childminders operating in rural areas, of which nearly 50 are women farmers. Participating in this network opened the opportunity to create new social relations with other childminders of the social cooperative (EXP014, EXP025). In particular, by attending the same training courses, women established a connection to each other. Besides the officially organized encounter opportunities, one interviewee mentioned the informal meetings with other classmates: "From our class we also meet once or twice a year and go out for pizza" (WOM013). A women farmer talked about a WhatsApp group she created with other childminders from the training course, where they share their experiences. The interviewee who has been part of the network for the longest time has made long lasting relations to other women farmers: "I have made many acquaintances, [ ... ] and also friendships have developed" (WOM002). On the contrary, the limited time resources and the spatial distribution of the network members hindered their frequent meeting.

\section{3. "Power Within"}

This section refers to women farmers' feeling of having developed a stronger sense of self thanks to their job as childminder. "Power within" includes the development of self-esteem and the ability of individuals to see themselves as agents of change.

\subsubsection{Changes in Character and Wellbeing}

Women farmers recognized personal development as a consequence of their engagement in childcare services. This included the acknowledgement of their own strengths and weaknesses as well as of their ability to make good choices. The interviewees have stated that the activity as childminder increased their wellbeing: "I've just grown at work [ ... ]. They [the children] just like to be there and that is the best thing for me" (WOM002). "That was the best decision I could make" (WOM009). Women farmers with a former off-farm job especially recognized significant increase in their wellbeing: "I simply have no more stress; I am well now. Compared to before, when I was always in a hurry, [ ... ]. Now I have become calmer" (WOM009). The wellbeing of women farmers also increased thanks to the attainment of autonomy and of appreciation: "[ ... ] the parents also see what the children are learning and this support, the feedback from them is simple, it just strengthens a lot" (WOM011). "I feel more 
self-confident, because you are your own boss and because you also have so much responsibility" (WOM010).

The entrepreneurial activity-their own project-and their economic responsibility on the farm enhanced interviewees' self-confidence; the recognition from their family and community contributed to their feeling of self-realization and wellbeing. One women farmer claimed that the work with children raised her family's appreciation of her. Although, for some women farmers, it took some time before the neighbors and the community could understand the activity and the reason that they started to offer farm-based childcare service, the majority of the interviewed women state that they currently feel recognized by the community for what they do. "At the beginning it was a bit strange for many people that this was offered on a farm, but now everyone knows that it needs a lot of care. The parents have to go to work. [ ... ] the work with nature, with the animals, the parents like that much more, compared to the KITA [nursery]. [ ... ] And I think it [the community] accepts and sees that as an important social contribution that one can make" (WOM002). Women farmers feel appreciated for the skills of educating children in nature, for the transmission of rural values, and for the positive and lively atmosphere they create in the village. Finally, offering farm-based social services increases the visibility of the manifold skills and competences of women farmers at a societal level.

\subsubsection{Changes in Attitudes}

According to one woman, the activity as childminder became more than a job for the women, it became part of their personalities (WOM010). It seems that, in addition to their role of being a women farmer, they feel they are professional childminders. The responsibility towards non-family children changed their working attitude: "It is a profession, you have a responsibility, you have an education and you have to follow certain things, rules and such" (WOM010). They recognized that their care-giving work is important to help other parents in reconciling family-and working life: "when I take a day off, five parents have to take their day off" (WOM012). Women farmers recognized that the family farm itself acquired a pedagogical function, educating children towards nature, rurality, and agricultural lifestyle. In their eyes, the farm became a place of social and inter-generational encounter. In addition, the awareness of being employed in the social cooperative made women farmers work in a more organized and structured manner, as well as acquire the capacity of separating working and private spheres. Still, some women farmers have not yet succeeded in developing this capacity and have consequently overloaded themselves with work. Others, however, have succeeded by delegating small farm and household duties to their family members, and have thereby reduced their workload.

\subsubsection{Future Prospects}

The interviewees reported being aware of the societal necessity they are satisfying through their service provision. Some of them even think that the demand for farm-based childcare services will increase in the future: "I think that it will become more and more that the parents will return to such things, because it's good for them [the children], the contact with the animals, with dirt, with mud [ ... ]" (WOM009). Parents seek a place where children can develop individually and experience freedom. Additionally, women farmers recognize that socioeconomic models are evolving towards an earlier return of working mothers to their employment after the birth of their child, which increases the demand for more flexible childcare services in general. Women farmers for their part recognize the potential of providing farm-based childcare services for their future as inhabitants of the rural areas: " $[\ldots]$ when you're a childminder, you're always on the farm, [ ... ] that's just important. And when you also have your own children, you can stay working here and earn more money" (WOM011).

\section{Discussion}

A gendered organization of farming tasks in a peculiar ethno-linguistic context was the starting situation in which South Tyrolean women farmers decided to engage in offering farm-based childcare 
services. They saw it as unquestionable to follow their traditional roles in agriculture [72]; to care for their own children, to do the housekeeping, and to stay at the farm if the husband had to work off-farm. Therefore, achieving or maintaining financial autonomy through a job outside the farm was not a desirable option for them. Their motivations to start the activity as childminder reflect the attempt to make the best of their situation and to acquire their own field of action with an economic outcome.

As a consequence of social farming activities, diverging paths of "feminization" and "masculinization" appear relevant in the South Tyrolean agricultural sector. In this regard, our results show different developments; that is, farm-based childminders previously working full-time on the farm and being available for different farming tasks have reduced their engagement in agriculture because of limited time capacities. Therefore, in some cases, agricultural production returned to be a rather "masculine" area of responsibility. This trend is similar to what has been observed in other contexts, where off-farm work of women farmers increased [75]. In contrast, the presence of women farmers through their on-farm side-activity and their availability for urgent farming tasks encouraged, in some cases, male farmers to work off-farm. In these situations, farm-based childminding fostered the "feminization" of agriculture. That was also reported in the case of Norway, where agritourism and Green Care ventures led to a retention of young women on farms [12].

Besides these trends, from this study, it clearly emerges that women farmers have used their capabilities to cross the boundaries of agriculture [19] and to start an entrepreneurial activity that meets social needs [50]. In so doing, they have set the base for putting the framework of traditional and patriarchal agriculture under discussion, whether intentionally or not. The provision of childcare services had positive impacts on women farmers' empowerment, similar to what was noted in the context of social entrepreneurship in developing countries $[21-23,44,45]$ and in countries of the global North $[16,54]$. However, this study identifies some limitations of the empowerment potential of being a farm-based childminder.

First of all, women farmers were able to act upon their decision to offer childcare services, even though the needs of their families, as well as their duties on the farm and in the household, had a strong influence, limiting their decision-making power. The limited access to "time resources" for offering childcare services required negotiation skills, or "power to", in order to free up such resources. To be able to manage all the tasks, some women farmers have sacrificed their free time, as well as time for excursions and for social contact. It is evident that farm diversification adds workload to women farmers $[5,28,76]$ and that, especially in agriculture, the combination of paid work and family work [77] could result in a disturbed work-life balance. This issue could discourage some women farmers from pursuing social farming activities. At the same time, the interviewees did not complain about their challenging living and working conditions and expressed their acceptance of overwhelming hours of work. According to Price [78] cit. in Fieldsand [5], women farmers tend to reject the claim that they are over-burdened because of their attachment to the traditional agricultural lifestyle and their wish to preserve the traditional farming system. This is confirmed by Alkhaled and Berglund [47], who showed that although women empower themselves, they are not emancipated; they act within their cultural system and sustain the family farm through the fulfilment of multiple tasks.

Secondly, the successful work of the social cooperative demonstrates the collective ability of the South Tyrolean women farmers to gain "power with". Indeed, the social cooperative enables women farmers to get trained in nature pedagogics; it facilitates the work of the childminders by taking over bureaucratic and lobby tasks. In turn, by engaging in an entrepreneurial activity, women farmers took control over their lives within the structures in which they live [79]. One women farmer, in particular, has led the development process of the collective power-gaining: the former spokesperson-today, the president of the social cooperative-gave women farmers a voice in rural society. With her political status as a member of the provincial parliament, she significantly influenced the working and living conditions of women farmers working as childminders. The case of the social cooperative shows that the success of a collective initiative is strongly dependent on a highly motivated leading person. From a different point of view, the concentration of "power with" in one person could be considered as 
a weak point of the initiative; in the case of absence of the leading personality, the collective dimension of power could also be endangered.

Thirdly, reflecting on the entrepreneurial activity itself, there is room for discussion on the potential to acquire "power within" by taking over a typical female duty [6]. With the provision of childcare services, women farmers may perpetuate the traditional gender roles in agriculture and remain in their domestic working sphere. They commodify their reproductive role and their contribution to a domestic and community life, which helps them to legitimize their business activities [80]. As also demonstrated by this study, it was predominantly the economic outcome of the entrepreneurial activity that made male famers accept their wives' activity. Additionally, social services such as childcare, generally implemented mainly by females, are poorly paid [81]. This is another concern regarding the empowerment potential of this type of activity within farm diversification. Brandth [20] provides a summary of the situation of women farmers in todays' farming society; the author underlines the persistence of patriarchal values in the division of tasks, also if they are challenged by the changing reality of women's and men's modern working lives linked to post-modernity. As for the case of women farmers engaged in agritourism [6], our findings suggest that the interviewees experience "autonomy within dependence". This leads to the conclusion that the provision of farm-based childcare services only partly helped women farmers to break out from their typical roles on the farm, as it maintains their reproductive and domestic positions. Women farmers engaging in social farming activities in South Tyrol moved within their limited field of action, characterized by typical female duties, without challenging the traditional system.

Finally, the ethno-linguistic context of women farmers providing childcare services in South Tyrol cannot be ignored in this analysis. A reflection on historically explained behaviors of farming families allows some considerations addressing the effects of women farmers' empowerment in South Tyrol. Women farmers engage in social farming activities in order to support the maintenance of their family farms [66]. This decision allows them to preserve the traditional agricultural lifestyle and their identity linked with their historical background [68], even if that means acting within a limited field of actions. With the new entrepreneurial activity, they develop a new set of values linked to specialization and formalization of work [82], and they gain power and a new role on the farm. However, their multi-engagement in a paid formal profession as childminders, and in unpaid activities like housekeeping and childrearing and in farming, may in turn challenge the system they aim to preserve. In fact, the work-overload of women farmers could endanger the socioeconomic viability of family farms, by limiting the time dedicated to traditional farming duties, and by causing tensions among family members, because of reduced privacy and the women's perception of unfairness in tasks division [83]. This scenario could also be interpreted according to Archer's social theory of the interplay between culture and agency cit. in the works of $[84,85]$. The interplay is created between the cultural system, that is, the peculiar ethno-linguistic context of farming in South Tyrol characterized by patriarchy, and the agent, that is, a group of women farmers willing to empower themselves. The interplay between the two could lead to elaboration, and thus the system's change towards emancipation, in the moment where the cultural conditions are unacceptable and determine women farmers' willingness to act towards change. On the contrary, if the will of women farmers to protect their interests within the ethno-linguistic context is stronger than the will to surpass the patriarchal system, the latter remains unchanged.

\section{Conclusions}

The provision of childcare services in the frame of social farming has become an appreciated entrepreneurial activity of women farmers in South Tyrol. This paper aimed to show the empowerment potential of providing childcare services for women farmers. Referring to the results, South Tyrolean women farmers offering childcare services experienced "power to" by becoming responsible for their own entrepreneurial activity and by acquiring the access to resources. In order to achieve the skills required to start an entrepreneurial activity, the network of women farmers working as childminders 
have organized specific training courses focusing on nature pedagogics. Additionally, target-specific marketing and the coordination of matching childminders and parents led to the professionalization of the service offer. Through the political influence of the network leader, the working conditions of childminders could also be improved. All these achievements fall into the dimension of "power with". Women farmers achieved "power within" through their awareness of doing a visible and valued job for the community and through the positive image of their work, which resulted in the development of self-confidence and wellbeing. However, the development of women farmers towards empowerment is contingent to the continuity of gendered division of labor on the family farm; in addition to their entrepreneurial activity, women farmers are in many cases still responsible for housekeeping, farming tasks, and caring for their own children. This results in a high workload and little free time. As the new activity required women farmers' investment of time resources and the agricultural work had to be reorganized and redistributed among the family members, the engagement in social farming practices is a family decision. Consequently, women farmers' decision to become a childminder was dependent on the agreement of the husband and the children. These results suggest the limitations of the empowerment potential of social farming for women in South Tyrol and are in line with those of Annes \& Wright's [6] study, which states that women farmers "experience autonomy, within dependence". Although this kind of empowerment does not imply the total abandonment of patriarchal values in South Tyrolean family farms, it seems that social farming could be a future perspective for women farmers that want to stay in a rural environment and to preserve their cultural/ethnolinguistic identity. Instead of claiming decision-making power over the entire family farm, women farmers accept to manage their own business within the farm environment and, in doing so, are able to acquire some space for their self-development. The case of South Tyrolean women farmers providing childcare services discussed here can be considered a clear example of the ongoing tension between farming tradition and modernization in mountain territories.

Author Contributions: Conceptualization, C.D.T. and V.G.; methodology, C.D.T., V.G., and A.M.; software, V.G. and C.D.T.; formal analysis, V.G. and C.D.T.; investigation, C.D.T. and V.G.; resources, C.D.T. and V.G.; data curation, V.G. and C.D.T.; Writing-Original draft preparation, V.G. and C.D.T.; Writing-Review and editing, V.G., C.D.T., and A.M.; supervision, A.M.; project administration, C.D.T and V.G. All authors have read and agreed to the published version of the manuscript.

Funding: This research was funded by the European Union's Horizon 2020 research and innovation programme under Grant Agreement No 677622 and the APC was funded by Eurac Research.

Acknowledgments: Many thanks to all our interview partners for sharing their experience and knowledge and to Jessica Lucy Delves for the linguistic revision.

Conflicts of Interest: The authors declare no conflict of interest.

\section{References}

1. FAO. The State of Food and Agriculture. Women in Agriculture-Closing the Gender Gap for Development; FAO: Rome, Italy, 2011.

2. Alkire, S.; Meinzen-Dick, R.; Peterman, A.; Quisumbing, A.; Seymour, G.; Vaz, A. The Women's Empowerment in Agriculture Index. World Dev. 2013, 52, 71-91. [CrossRef]

3. Sraboni, E.; Malapit, H.J.; Quisumbing, A.R.; Ahmed, A.U. Women's Empowerment in Agriculture: What Role for Food Security in Bangladesh? World Dev. 2014, 61, 11-52. [CrossRef]

4. EIGE. Gender in Agriculture and Rural Development; European Institute for Gender Equality: Vilnius, Lithuania, 2016.

5. Fieldsand, A. Out of the shadows: Making female labour in agriculture visible. Econ. Rural Dev. 2008, 4, $16-25$.

6. Annes, A.; Wright, W. 'Creating a room of one's own': French farmwomen, agritourism and the pursuit of empowerment. Women's Stud. Int. Forum 2015, 53, 1-11. [CrossRef]

7. Haugen, M.S. Female farmers in Norwegian agriculture. From traditional farm women to professional farmers. Sociol. Rural. 1990, 30, 197-209. [CrossRef]

8. Saugeres, L. Of Tractors and Men: Masculinity, Technology and Power in a French Farming Community. Sociol. Rural. 2002, 42, 143-159. [CrossRef] 
9. Trauger, A.; Sachs, C.; Barbercheck, M.; Kiernan, N.E.; Brasier, K.; Findeis, J. Agricultural education: Gender identity and knowledge exchange. J. Rural Stud. 2008, 24, 432-439. [CrossRef]

10. Quisumbing, A.R.; Meinzen-Dick, R.; Raney, T.L.; Croppenstedt, A.; Behrman, J.A.; Peterman, A. Closing the Knowledge Gap on Gender in Agriculture. In Gender in Agriculture-Closing the Knowledge Gap; Quisumbing, A.R., Meinzen-Dick, R., Raney, T.L., Croppenstedt, A., Behrman, J.A., Peterman, A., Eds.; FAO and Springer: Dodrech, The Nederland, 2014; pp. 3-31.

11. Bock, B.B. Fitting in and Multi-tasking: Dutch Farm Women's Strategies in Rural Entrepreneurship. Sociol. Rural. 2004, 44, 245-260. [CrossRef]

12. Heggem, R. Diversification and Re-feminisation of Norwegian Farm Properties. Sociol. Rural. 2014, 54, 439-459. [CrossRef]

13. Wright, W.; Annes, A. Farm Women and the Empowerment Potential in Value-Added Agriculture. Rural Sociol. 2016, 81, 545-571. [CrossRef]

14. Mettepenningen, E.; Dessein, J.; Mieke, C.; Van Huylenbroeck, G. Green Care in the framework of multifunctional agriculture. In The Economics of Green Care in Agriculture; Dessein, J.B., Bock, B., Eds.; Loughborough University: Loughborough, UK, 2010; pp. 46-53.

15. Dessein, J.; Bock, B. The Economics of Green Care in Agriculture; Loughborough University: Loughborough, UK, 2010.

16. Di Iacovo, F.; O'Connor, D. Supporting Policies for Social Farming in Europe. Progressing Multifunctionality in Responsive Rural Areas; ARSIA: Firenze, Italia, 2009.

17. Van der Ploeg, J.D. Revitalizing Agriculture: Farming Economically as Starting Ground for Rural Development. Sociol. Rural. 2000, 40, 497-511. [CrossRef]

18. Calás, M.B.; Smircich, L.; Bourne, K.A. Extending the boundaries: Reframing “entrepreneurship as social change" through feminist perspectives. Acad. Manag. Rev. 2009, 34, 552-569. [CrossRef]

19. Seuneke, P.; Bock, B. Exploring the roles of women in the development of multifunctional entrepreneurship on family farms: An entrepreneurial learning approach. NJAS Wagening. J. Life Sci. 2015, 74-75, 41-50. [CrossRef]

20. Brandth, B. Gender Identity in European Family Farming: A Literature Review. Sociol. Rural. 2002, 42, 181-200. [CrossRef]

21. Haugh, H.M.; Talwar, A. Linking Social Entrepreneurship and Social Change: The Mediating Role of Empowerment. J. Bus. Ethics 2016, 133, 643-658. [CrossRef]

22. Datta, P.B.; Gailey, R. Empowering Women Through Social Entrepreneurship: Case Study of a Women's Cooperative in India. Entrep. Theory Pract. 2012, 36, 569-587. [CrossRef]

23. Maguirre, M.V.; Ruelas, G.C.; De La Torre, C.G. Women empowerment through social innovation in indigenous social enterprises. Revista de Administração Mackenzie 2016, 17, 164-190. [CrossRef]

24. Hoffmann, C.; Streifeneder, T. Social Agriculture-A diversification-potential in South Tyrol and Trentino. Jahrbuch der Österreichischen Gesellschaft für Agrarökonomie 2013, 23, 91-100.

25. Rowlands, J. Empowerment examined. In Development and Social Diversity; Eade, D., Ed.; Oxfam: Oxford, UK, 1996; pp. 86-95.

26. Kabeer, N. Resources, agency, achievements: Reflections on the measurement of women's empowerment. Dev. Chang. 1999, 30, 435-464. [CrossRef]

27. Schmitt, M. Landwirtinnen. Chancen und Risiken von Frauen in einem traditionellen Männerberuf; Leske und Buderich: Opladen, Germany, 1997.

28. Contzen, S.; Forney, J. Family farming and gendered division of labour on the move: A typology of farming-family configurations. Agric. Hum. Values 2017, 34, 27-40. [CrossRef]

29. Wunderli, R. Ohne sie geht es nicht: Zur ökonomischen Relevanz von Familie in der schweizerischen Berglandwirtschaft seit 1950. Zeitschrift für Geschichte - Revue d'histoire 2014, 21, 103-113.

30. Tunst-Kamleitner, U.; Larcher, M.; Vogel, S. Women in 50 years agricultural reports-A gender-specific analysis. Jahrbuch der Österreichischen Gesellschaft für Agrarökonomie 2011, 20, 75-84.

31. Oedl-Wieser, T. Frauen und Politik am Land; Bundesanstalt für Bergbauernfragen: Vienna, Austria, 2006.

32. Cavicchioli, D.; Bertoni, D.; Pretolani, R. Farm succession at a crossroads: The interaction among farm characteristics, labour market conditions, and gender and birth order effects. J. Rural Stud. 2018, 61, 73-83. [CrossRef]

33. Wiest, K. Women and Migration in Rural Europe. Labour Markets, Representations and Policies; Palgrave and Macmillan: Basingstoke, UK, 2016. 
34. Bock, B.B. Gender and Mobility. In Gender and Rural Globalization: International Perspectives on Gender and Rural Development; Bock, B.B., Shortall, S., Eds.; CABI: Oxfordshire, UK; Boston, MA, USA, 2017; pp. 8-19.

35. Oedl-Wieser, T. Was ist dran am Exodus der Frauen vom Land? Gründe für geschlechterselektive Abwanderung und deren Konsequenzen für ländliche Regionen; Factsheet Nr. 14; Bundesanstalt für Bergbauernfragen: Vienna, Austria, 2017.

36. Morris, C.; Little, J. Rural Work: An Overview of Women's Experiences. In Critical Studies in Rural Gender Issues; Little, J., Morris, C., Eds.; Ashgate Publishing: Aldershot, UK, 2005; pp. 9-27.

37. Oedl-Wieser, T.; Wiesinger, G. Landwirtschaftliche Betriebsleiterinnen in Österreich-Eine explorative Studie zur Identitätsbildung; Bundesanstalt für Bergbauernfragen: Vienna, Austria, 2010.

38. Bäschlin, E. Freizeit: Da mache ich einfach nichts! In Frauen in der Landwirtschaft_Debatten aus Wissenschaft und Praxis; Bäschlin, E., Contzen, S., Helfenberger, R., Eds.; eFeF Verlag Ag: Bern/Wettingen, Switzerland, 2013; pp. 171-187.

39. Steinbacher, M.; Schmitt, M. Bäuerinnen als Pädagoginnen. In Frauen in der Landwirtschaft-Debatten aus Wissenschaft und Praxis; Bäschlin, E., Contzen, S., Helfenberger, R., Eds.; eFeF Verlag Ag: Bern/Wettingen, Switzerland, 2013; pp. 121-141.

40. Van Huylenbroeck, G.; Vandermeulen, V.; Mettepenningen, E.; Verspecht, A. Multifunctionality of Agriculture: A Review of Definitions, Evidence and Instruments. Living Rev. Landsc. Res. 2007, 1, 5-43. [CrossRef]

41. Woolf, V. A Room of One's Own; Hogarth Press: London, UK, 1929.

42. Hochschild, A. The Second Shift: Working Parents and the Revolution at Home; Viking: New York, NY, USA, 1989.

43. European Commission. Women in EU agriculture and rural areas: Hard work, low profile. In EU Agricultural Economic Briefs; Brief N.7; European Commission: Brussels, Belgium, 2012.

44. Kimbu, A.; Ngoasong, M. Women as vectors of social entrepreneurship. Ann. Tour. Res. 2016, 60, 63-79. [CrossRef]

45. Sidhu, K.; Kaur, S. Development of Entrepreneurship among Rural Women. J. Soc. Sci. 2006, 2, 147-149. [CrossRef]

46. Akter, S.; Rutsaert, P.; Luis, J.; Htwe, N.M.; San, S.S.; Raharjo, B.; Pustika, A. Women's empowerment and gender equity in agriculture: A different perspective from Southeast Asia. Food Policy 2017, 69, $270-279$. [CrossRef]

47. Alkhaled, S.; Berglund, K. 'And now I'm free': Women's empowerment and emancipation through entrepreurship in Saudi Arabia and Sweden. Entrep. Reg. Dev. 2018, 7, 877-900. [CrossRef]

48. Inglis, T. Empowerment and Emancipation. Adult Educ. Q. 1997, 48, 3-17. [CrossRef]

49. Ali, R. Empowerment beyond resistance: Cultural ways of negotiating power relations. Women's Stud. Int. Forum 2014, 45, 119-126. [CrossRef]

50. Sud, M.; Van Sandt, C.V.; Baugous, A. Social Entrepreneurship: The Role of Institutions. J. Bus. Ethics 2009, 85, 201-216. [CrossRef]

51. De Leonardis, O.; Mauri, D.; Rotelli, F. L'impresa Sociale; Anabasi: Milano, Italy, 1994.

52. Bock, B. Social innovation and sustainability; how to disentangle the buzzword and its application in the field of agriculture and rural development. Stud. Agric. Econ. 2012, 114, 57-63. [CrossRef]

53. Mayring, P. Qualitative Inhaltsanalyse. Grundlagen und Techniken; 11., aktualisierte und überarbeitete Auflage; Beltz Verlag: Weinheim, Germany; Basel, Switzerland, 2010.

54. Steinicke, E.; Waldner, J.; Löffler, R.; Beismann, M. Autochthonous Linguistic Minorities in the Italian Alps: New Legislation-New Identifications-New Demographic Processes. J. Alp. Res. 2011, 99-2, 1-15. [CrossRef]

55. ASTAT. Demografische Daten für Südtirol 2017. Available online: https://astat.provinz.bz.it/de/aktuellespublikationen-info.asp?news_action=4\&news_article_id=618003 (accessed on 8 January 2020).

56. Vogel, S.; Maurer, O.; Wytrzens, H.K.; Larcher, M. Perceptions of Mountain Farming in South Tyrol: Cultural Differences in a Border Region. In Proceedings of the Man in the Landscape across Frontiers-IGU-LUCC Central Europe Conference 2007, Prague, Czech Republic, 28 August-4 September 2007; pp. 209-220.

57. Schweigkofler, A. South Tyrol: Rethinking Ethnolinguistic Vitality. In German Minorities in Europe: Ethnic Identity and Cultural Belonging; Wolff, S., Ed.; Berghahn Books: New York, NY, USA; Oxford, UK, 2000; pp. 63-73.

58. Carlà, A. South Tyrolean Solutions to Ethnic Conflicts from a Security Perspective. Ethnopolitics Pap. 2016, 6, 41 .

59. Levy, C. Italian Regionalism: History, Identity and Politics; Berg Publishers: Oxford, UK, 1996. 
60. Carlà, A. Living Apart in the Same Room: Analysis of the Management of Linguistic Diversity in Bolzano. Ethnopolitics 2007, 6, 285-313. [CrossRef]

61. Baur, P.; Pezzati, M.; Rieder, P.; Schluep, I. Südtiroler Landwirtschaft: Agrarökonomische Analysen und Perspektiven; Institut für Agrarwirtschaft: Zürich, Switzerland, 1998.

62. Grote, G. The South Tyrol Question, 1866-2010: From National Rage to Regional State; Peter Lang: Bern, Switzerland, 2012.

63. Autonome Provinz Bozen-Südtirol. Agrar- und Forstbericht 2017; Self-published: Bozen, Italy, 2018.

64. European Commission. Statistical Factsheet Italy. In Retrieved from Agriculture in the European Union and the Member States; European Commission: Brussels, Belgium, 2019. Available online: https://ec.europa.eu/ agriculture/statistics/factsheets_en (accessed on 23 October 2019).

65. Alcock, A. The South Tyrol Autonomy. A Short Introduction; County Londonderry: Bolzano, Italy, 2001.

66. Cole, J.W.; Wolf, E.R. The Hidden Frontier: Ecology and Ethnicity in an Alpine Valley; University of California Press: Berkeley, CA, USA, 1999.

67. Hudson, M.J.; Aoyama, M.; Diab, M.C.; Aoyama, H. The South Tyrol as Occupation scape: Occupation, Landscape, and Ethnicity in a European Border Zone. J. Occup. Sci. 2011, 18, 21-35. [CrossRef]

68. Kaplan, D.H. Conflict and Compromise among Borderline Identities in Northern Italy. Tijdschrift voor Economische en Sociale Geografie 2000, 91, 44-60. [CrossRef]

69. ASTAT. Frauen in der Landwirtschaft. astatinfo 2016, 10, 68.

70. EUROSTAT. Archive: Farmers in the EU—Statistics. Available online: https://ec.europa.eu/eurostat/statisticsexplained/index.php/Farmers_in_the_EU_-_statistics (accessed on 15 May 2019).

71. Matscher, A.; Larcher, M.; Vogel, S.; Maurer, O. Self-perception of farming women in South Tyrol. Jahrbuch der Österreichischen Gesellschaft für Agrarökonomie 2009, 18, 43-53.

72. Matscher, A.; Larcher, M.; Vogel, S.; Maurer, O. Zwischen Tradition und Moderne: Das Selbstbild der Südtiroler Bäuerinnen. Zeitschrift für Agrargeschichte und Agrarsoziologie 2008, 2, 71-84.

73. Wiesinger, G.; Quendler, E.; Hoffmann, C.; Di Martino, A.; Egartner, S.; Weber, N.; Hambrusch, J. Soziale Landwirtschaft. Situation und Potenziale einer Form der Diversifizierung land- und forstwirtschaftlicher Betriebe in Österreich, Südtirol und Trentino; Bundesanstalt für Bergbauernfragen: Vienna, Austria, 2013.

74. Südtiroler Bäuerinnenorganisation. Soziale Landwirtschaft in Südtirol; Self-Published: Bolzano, Italy, 2017.

75. Clarke, J.; Alston, M. Australia-Understanding the "local" and "global": Intersections engendering change for women in family farming in Australia. In Women in Agriculture Worldwide; Fletcher, A.J., Kubik, W., Eds.; Routledge: Oxon, UK; New York, NY, USA, 2016; pp. 27-36.

76. Lanfranchi, M.; Giannetto, C.; Abbate, T.; Dimitrova, V. Agriculture and the Social Farm: Expression of the Multifunctional Modell of Agriculture as a Solution to the Social Crisis in Rural Areas. Bulg. J. Agric. Sci. 2015, 21, 711-718.

77. Viganò, G. Conciliare Famiglia e Lavoro in Un'area Rurale Alpina; FrancoAngeli: Milano, Italia, 2014.

78. Price, L.A. New Farming Subsidy? Women, Work and Family Farm Survival. J. Royal Agric. Soc. Engl. Annu. Publ. 2006, 167, 49-58.

79. Al-Dajani, H.; Marlow, S. Empowerment and entrepreneurship: A conceptual framework. Int. J. Entrep. Behav. Res. 2013, 19, 503-524. [CrossRef]

80. Morris, C.; Evans, N. 'Cheese makers are always women': Gendered representations of farm life in the agricultural press. Gender Place Cult. J. Fem. Geogr. 2001, 8, 375-390. [CrossRef]

81. Giraldi, M. Employment in the Care Sector of Europe; EASPD: Brussels, Belgium, 2010.

82. Giddens, A. Fondamenti di Sociologia; Il Mulino: Bologna, Italia, 2006.

83. Mary Blair-Loy, A.H. Stability and transformation in gender, work, and family: Insights from the second shift for the next quarter century. Community Work Fam. 2015, 18, 435-454. [CrossRef]

84. Archer, M.S. Culture and Agency: The Place of Culture in Social Theory; Cambridge University Press: Cambridge, UK, 1996.

85. Zeuner, L. Review essay: Margaret Archer on Structural and Cultural Morphogenesis. Acta Sociol. 2000, 42, 79-86. [CrossRef]

(C) 2020 by the authors. Licensee MDPI, Basel, Switzerland. This article is an open access article distributed under the terms and conditions of the Creative Commons Attribution (CC BY) license (http://creativecommons.org/licenses/by/4.0/). 